\title{
Editorial \\ The New Voice for the New Era of Thalassemia Reports
}

\author{
Aurelio Maggio
}

check for

updates

Citation: Maggio, A. The New Voice for the New Era of Thalassemia

Reports. Thalass. Rep. 2022, 12, 12-13. https://doi.org/10.3390/ thalassrep12010003

Received: 27 December 2021 Accepted: 27 December 2021 Published: 13 January 2022

Publisher's Note: MDPI stays neutral with regard to jurisdictional claims in published maps and institutional affiliations.

Copyright: (C) 2022 by the author. Licensee MDPI, Basel, Switzerland. This article is an open access article distributed under the terms and conditions of the Creative Commons Attribution (CC BY) license (https:// creativecommons.org/licenses/by/ $4.0 /)$.
Department of Haematolgy, Oncology and Genetics, Campus of Haematology Franco and Piera Cutino, AOR Villa Sofia-V. Cervello, 90100 Palermo, Italy; md.amaggio@gmail.com

The recent transfer of Thalassemia Reports, the only journal fully dedicated on Thalassemia, from PagePress to MDPI was great news for those who contributed to the spread of the journal. Our editorial and publishing teams appreciate the help of PagePress publishing in making this a very smooth transition.

Our journal has been including all people who have been involved in making a relevant contribution to thalassemia management and research. The main goal of this open-access journal was to carry ahead with a look at two crucial issues.

The first was to give voice to all groups working in developing countries where thalassemia and haemoglobinopathies are most common and where the progresses for the control and management of these diseases have been more impressive and relevant.

The second one was to give room to the Association of Thalassemia Patients. This was one of the reasons why Thalassemia Reports published recommendations and papers submitted by the Thalassemia International Federation.

The challenge for the next years will be to give voice to the amazing changes in the treatment of these diseases, looking at the all innovative treatments that are coming to the bed of the patients.

Indeed, the scenario of curing thalassemia and hemoglobinopathies is dramatically changing and cell erythroid maturation [1], gene therapy [2] and gene editing [3] are the new paradigm approaches with which we have to face in the next years.

This journal would like to address, during the next years, these issues, looking, at the same time, at giving voice to any claim for guaranteeing worldwide access to these new treatments. This is a crucial issue, above all after the announcement, on Monday 23 August 2021, by Bluebird-bio to end commercial operations in Europe for gene therapy, claiming that it has been too difficult to convince European Union member governments to pay high prices upfront for treatments.

Therefore, all of you are invited to submit your experience and your research on this journal for contributing to reaching these ambitious aims of Thalassemia Reports [4].

Have a nice and wonderful 2022!

Conflicts of Interest: The author is Advisory Board member of Novartis, Cell Gene-Corp and Bristol Meyers Squibb, Bluebirdbio, Vertex. 


\section{References}

1. Maggio, A. Cell erythroid maturation approach: A new paradigm in the road map towards a cure for beta-thalassaemia syndromes. Br. J. Haematol. 2021. [CrossRef] [PubMed]

2. Locatelli, F.; Thompson, A.; Kwiatkowski, J.; Porter, J.; Thrasher, A.; Hongeng, S.; Sauer, M.; Thuret, I.; Lal, A.; Algeri, M.; et al. Betibeglogene Autotemcel Gene Therapy for Non- $\beta 0 / \beta 0$ Genotype $\beta$-Thalassemia. N. Engl. J. Med. 2021. [CrossRef] [PubMed]

3. Frangoul, H.; Altshuler, D.; Domenica Cappellini, M.; Chen, Y.; Domm, J.; Eustace, B.; Foell, J.; de la Fuente, J.; Grupp, S.; Handgretinger, R.; et al. CRISPR-Cas9 Gene Editing for Sickle Cell Disease and $\beta$-Thalassemia. N. Engl. J. Med. 2021, 384, $252-260$. [CrossRef] [PubMed]

4. Thalassemia Reports. Available online: https://www.mdpi.com/journal/thalassrep (accessed on 31 December 2021).

\section{Short Biography of Authors}

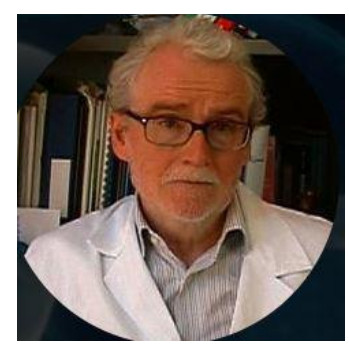

Aurelio Maggio is actually Director of the Department of Hematology and Oncology at A.O.O.R. "Villa Sofia-Cervello" of Palermo, Director of the U.O.C. of "Hematology for rare diseases of blood and hematopoietic organs" with Thalassemia of the Hospital A.O.O.R. "Villa-Sofia-Cervello" in which he coordinates the "Campus of Hematology Franco and Piera Cutino" a high specialized structure for the therapy of Thalassemia and others blood rare diseases www.villasofia.it; www.pieracutino. 